\title{
Metabolic alterations in patients with depression and their relationship to the etiology of depressive disorders
}

Kail G Kahl

\author{
From $1^{\text {st }}$ International Congress on Neurobiology and Clinical Psychopharmacology and European \\ Psychiatric Association Conference on Treatment Guidance \\ Thessaloniki, Greece. 19-22 November 2009
}

Major depressive disorder (MDD) is an independent risk factor for the development of type 2 diabetes (T2DM) and cardiovascular disorders (CVD). Vice versa, patients suffering from T2DM or CVD bear an elevated risk of developing MDD. Recent epidemiologic studies suggest that MDD promotes the development of the metabolic syndrome (MetS), a well known risk factor for the development of T2DM and CVD. Furthermore, patients at risk for type 2 diabetes have a higher incidence of the MetS after a lifetime episode of MDD. These results point to an important role of MDD in the development of T2DM and CVD, and a bidirectional modulation between MDD and T2DM/CVD. Several risk factors for the above mentioned associations have been described. Among these, a dysregulation of endocrine and immune systems, sedentary lifestyle and adverse health related behaviors have been found. Recently, a dysregulation of the central energy metabolism has been proposed as superordinated hypothesis to explain metabolic abnormalities in the context of depression. These findings expand our understanding of MDD as a complex, multietiological and multi-system disorder. As suggested by the joint recommendations of the EPA, EASD and ESC on diabetes and cardiovascular risk in patients with severe mental disorders, increased awareness of

Department of Psychiatry, Social Psychiatry and Psychotherapy, Hannover Medical School, Germany metabolic disorders is necessary in patients with depressive disorders.

Published: 22 April 2010

\section{doi:10.1186/1744-859X-9-S1-S34}

Cite this article as: Kahl: Metabolic alterations in patients with depression and their relationship to the etiology of depressive disorders. Annals of General Psychiatry 2010 9(Suppl 1):S34.
Submit your next manuscript to BioMed Central and take full advantage of:

- Convenient online submission

- Thorough peer review

- No space constraints or color figure charges

- Immediate publication on acceptance

- Inclusion in PubMed, CAS, Scopus and Google Scholar

- Research which is freely available for redistribution

Submit your manuscript at www.biomedcentral.com/submit
C Biomed Central 